\title{
Peran Eritromisin terhadap Toleransi Minum Bayi Prematur
}

\author{
Lily Indriasary Harahap, Asril Aminullah, Sudung O Pardede, Badriul Hegar \\ Departemen Ilmu Kesehatan Anak, Fakultas Kedokteran, Universitas Indonesia, RS. Dr. Cipto \\ Mangunkusumo, Jakarta
}

Latar belakang. Eritromisin merupakan salah satu obat prokinetik untuk mengatasi intoleransi minum pada
bayi prematur karena imaturitas sistem pencernaan. Beberapa penelitian mengenai efektifitas eritromisin
dalam mengatasi intoleransi minum akibat imaturitas saluran cerna masih merupakan kontroversi.
Tujuan. Mengetahui peran eritromisin dalam meningkatkan toleransi minum bayi prematur.
Metode. Penelitian uji kinis prospektif acak terkontrol tersamar ganda pada bulan September 2011 -Februari
2012 dengan subyek bayi prematur usia gestasi (UG) 28 -36 minggu. Diagnosis intoleransi minum ditetapkan
bila residu lambung lambung $\geq 25 \%$ jumlah pemberian minum 6 jam sebelumnya
Hasil. Terdapat 36 subyek bayi prematur dengan intoleransi minum yang dibagi menjadi 2 kelompok
yaitu 19 subyek mendapat eritromisin ( 3 mg/kgbb/dosis, $4 x$ sehari selama 7 hari) dan 17 subyek mendapat
plasebo berupa larutan sukrosa. Tidak terdapat perbedaan bermakna jumlah episode terjadinya residu
pada kedua kelompok ( $p=0,271)$, demikian juga dengan analisis subgrup pada UG $\leq 32$ minggu dan $>32$
minggu ( $p=0,25)$ dan ( $p=0,39)$. Median lama hari mencapai nutrisi enteral penuh antara kedua kelompok
tidak terbukti bermakna secara statistik ( $p=0,82$. Hasil yang tidak bermakna juga didapatkan pada UG
$\leq 32$ minggu dan $>32$ minggu ( $p=0,61)$ dan ( $p=0,60$.)
Kesimpulan. Pada penelitian ini pemberian eritromisin dosis rendah ( 3 mg/kgbb/dosis, setiap 6 jam) per
oral selama 7 hari tidak terbukti dapat mengurangi residu lambung maupun mempercepat pencapaian
nutrisi enteral penuh pada bayi prematur dengan UG $28-36$ minggu yang mengalami intoleransi minum.

Sari Pediatri 2013;15(3):167-73.

Kata kunci: eritromisin, intoleransi minum, bayi prematur.

\footnotetext{
Alamat korespondensi:

Prof. Dr. Asril Aminullah Sp.A(K), Divisi Perinatologi, Departemen Ilmu Kesehatan Anak, Fakultas Kedokteran Universitas Indonesia. Jl. Salemba no.6 Jakarta 10430. Telp. (021) 314 6811, 3918301 ext. 3133 Fax. (021)314 6811
}

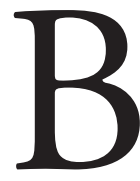
ayi dengan pemberian nutrisi yang adekuat memiliki peran penting dalam pertumbuhan dan perkembangan, serta meningkatkan ketahanan terhadap infeksi. Imaturitas sistem pencernaan, ketidakmampuan bayi untuk menghisap dan menelan, dan risiko terjadinya enterokolitis nekrotikans (EKN) merupakan tantangan dalam pemberian nutrisi pada bayi prematur. ${ }^{1}$ 
Pemberian makan secara dini dikenal sebagai salah satu bagian penting dari perawatan bayi prematur untuk mendorong pertumbuhan dan pematangan saluran cerna, peningkatan aktivitas enzim laktase dan motorik usus halus, pengurangan kejadian stress ulcer, penurunan angka komplikasi sepsis, dan peningkatan fungsi imunitas. ${ }^{2,3}$ Intoleransi minum menjadi salah satu penyebab tertundanya nutrisi enteral secara penuh dan membutuhkan nutrisi parenteral yang lebih lama. Pada bayi prematur, salah satu penyebab intoleransi minum adalah motilitas saluran cerna yang belum sempurna sehingga menyebabkan pengosongan lambung dan transit di usus yang lebih lambat dan meningkatkan residu di lambung. ${ }^{4}$

Pemberian nutrisi parenteral yang lama merupakan salah satu faktor predisposisi terjadinya infeksi nosokomial, disfungsi hati, kerusakan struktur dan fungsi saluran cerna, serta memperpanjang masa rawat inap. Kondisi ini dapat berujung pada atrofi mukosa usus sehingga pemberian nutrisi enteral yang adekuat penting dilakukan secepatnya setelah kelahiran. ${ }^{5}$

Salah satu upaya untuk mengatasi intoleransi minum pada bayi prematur adalah pemberian obat prokinetik untuk meningkatkan motilitas saluran cerna. Obat prokinetik yang biasa digunakan untuk mengatasi masalah dismotilitas pada anak seperti cisaprid, metoklopramid, dan domperidon memiliki efek samping yang serius. Metoklopramid dapat menyebabkan efek samping reaksi ekstrapiramidal, sedangkan cisaprid dapat menyebabkan aritmia jantung sehingga penggunaan kedua obat tersebut tidak dianjurkan lagi. Penggunaan domperidon sebagai salah satu obat prokinetik juga masih diperdebatkan..$^{6-8}$

Eritromisin merupakan antibiotik golongan makrolid yang memiliki efek menyerupai motilin terhadap motilitas saluran cerna, bekerja sebagai agonis motilin dengan cara berikatan dengan reseptor motilin pada antrum dan duodenum bagian atas. Beberapa uji klinis juga menunjukkan eritromisin dapat meningkatkan motilitas lambung pada anak pasca-operasi dengan penyulit dismotilitas usus, juga pada anak dengan pseudoobstruksi kronis. ${ }^{8}$ Dewasa ini, penggunaan eritromisin sebagai obat prokinetik diperluas pada bayi prematur yang mengalami intoleransi minum namun peran klinisnya masih menjadi kontroversi.?

Tujuan penelitian ini adalah untuk mengetahui peran eritromisin dalam meningkatkan toleransi minum bayi prematur.

\section{Metode}

Penelitian uji klinis prospektif acak terkontrol tersamar ganda (double blind randomized controlled trial) berlangsung di ruang rawat inap perinatologi Rumah Sakit Ibu dan Anak (RSIA) Budi Kemuliaan, Rumah Sakit Umum Daerah (RSUD) Tangerang, Rumah Sakit Umum (RSU) Koja, dan Rumah Sakit Umum (RSU) Hermina Grand Wisata. Penelitian berlangsung selama 6 bulan, yaitu sejak September 2011 sampai Februari 2012. Subyek penelitian adalah bayi prematur UG 2836 minggu dengan intoleransi minum, yaitu adanya residu lambung lebih dari $25 \%$ jumlah pemberian minum pada 6 jam sebelumnya. Subyek yang menderita suatu sindrom atau kelainan kongenital, kelainan anatomis saluran cerna, asfiksia pada saat lahir, adanya atau riwayat enterokolitis nekrotikans (EKN), dan sepsis tidak diikutsertakan. Obat atau plasebo diberikan setelah orang tua atau calon subyek menyatakan persetujuan dan menandatangani informed consent. Penetapan subyek mendapat obat atau plasebo dilakukan dengan cara randomisasi blok. Penelitian ini telah mendapat persetujuan dari Komite Etik Penelitian FKUI.

Susu diberikan pada setiap bayi prematur setelah bayi dalam keadaan stabil melalui pipa orogastrik tergantung berat badan (berat $<1500 \mathrm{~g}$ setiap 2 jam, $\geq 1500 \mathrm{~g}$ setiap $3 \mathrm{jam}$ ). Susu yang diberikan adalah ASI atau susu formula, lebih diutamakan ASI. Pemberian susu dimulai dengan volume $10 \mathrm{~mL} / \mathrm{kgbb} / \mathrm{hari}$, dan ditingkatkan bertahap sampai mencapai volume enteral penuh $(150 \mathrm{~mL} / \mathrm{kgbb} / \mathrm{hari})$. Residu lambung diukur per-6 jam dengan cara aspirasi melalui pipa orogastrik sebelum pemberian minum selanjutnya..

Bayi yang dialokasikan mendapat obat aktif akan menerima eritromisin etil suksinat oral $3 \mathrm{mg} / \mathrm{kgbb} /$ dosis setiap 6 jam selama 7 hari. Dosis ini dipilih untuk menghindari efek samping eritromisin dosis tinggi (hipertrofi stenosis pilorus, aritmia jantung). Pemberian eritromisin melalui jalur oral dipilih karena lebih praktis, murah, dan tidak invasif. Kelompok plasebo mendapat cairan sukrosa dengan jumlah yang sama. Pencatatan jumlah, sifat residu lambung, dan volume susu yang diberikan dilakukan oleh perawat yang blinded terhadap alokasi subyek.

Analisis statisitik dilakukan dengan program SPSS versi 17.0 menggunakan uji chi-square dan uji t tidak berpasangan atau Mann Whitney. Nilai p dianggap bermakna secara statistik jika $<0,05$. 


\section{Hasil}

Selama penelitian berjalan terdapat 8792 bayi yang lahir di empat rumah sakit tempat penelitian, dengan $803(9,13 \%)$ lahir prematur. Pada akhir masa penelitian yang ditetapkan diperoleh 48 subyek yang memenuhi kriteria inklusi. Lima subyek dieksklusi karena tidak mendapat persetujuan orangtua, 5 subyek dikeluarkan karena mengalami sepsis, dan 2 subyek pulang paksa atas permintaan orangtua. Pada akhir penelitian, diperoleh 36 subyek untuk dianalisis.

Kelompok yang diberikan eritromisin 19 dan plasebo 17 subyek. Tidak terdapat perbedaan bermakna antara jenis kelamin, usia gestasi, berat lahir, cara persalinan, skor APGAR menit pertama dan kelima, riwayat pemberian oksigen, usia saat subyek mulai minum, usia saat masuk dalam penelitian, serta jenis susu yang diberikan antara kelompok eritromisin dan plasebo (Tabel 1).

\section{Episode terjadinya residu selama pengobatan}

Median episode terjadinya residu selama pengobatan, yaitu 0 (0-4) kali pada kelompok eritromisin dan 1 (0-9) kali pada kelompok plasebo selama pemantauan. Terdapat perbedaan median episode terjadinya residu

Tabel 1. Perbandingan karakteristik subyek $(\mathrm{n}=36)$

\begin{tabular}{lcc}
\hline & \multicolumn{2}{c}{ Kelompok perlakuan } \\
\cline { 2 - 3 } Karakteristik subyek & Eritromisin $(\mathrm{n}=19)$ & Plasebo $(\mathrm{n}=17)$ \\
\hline Jenis kelamin & 8 & 9 \\
$\quad$ Laki-laki & 11 & 8 \\
$\quad$ Perempuan & 13 & 12 \\
Usia gestasi (minggu) & 6 & 5 \\
$\quad 28-32$ & & \\
$32-35$ & 10 & 10 \\
Cara persalinan & 9 & 7 \\
$\quad$ Spontan & $1631 \pm 417$ & $1588 \pm 287$ \\
Bedah kaisar & $7(5-8)$ & $7(5-8)$ \\
Berat lahir (g) \pm SB* & $8 \pm 1$ & $4(2-10)$ \\
Skor APGAR menit pertama (rentang) & $4(2-15)$ & $6(4-14)$ \\
Skor APGAR menit kelima \pm SB* & $7(4-18)$ & \\
Usia saat mulai minum dalam hari (rentang) & & 5 \\
Usia saat penelitian dalam hari (rentang) & 9 & 10 \\
Riwayat pemberian oksigen & 8 & 2 \\
$\quad$ Tanpa oksigen & 2 & 6 \\
$\quad$ Nasal kanul & & 4 \\
CPAP & 8 & 7 \\
Jenis susu yang diberikan & 7 & \\
$\quad$ ASI & 4 & 4 \\
Susu formula & & \\
Campuran & &
\end{tabular}

Keterangan:

$* \mathrm{SB}=$ simpang baku

Tabel 2. Episode terjadinya residu selama pengobatan dan lama hari mencapai nutrisi enteral penuh setelah perlakuan

\begin{tabular}{lccc}
\hline & \multicolumn{3}{c}{ Jenis perlakuan } \\
\cline { 2 - 4 } & Eritromisin $(\mathrm{n}=19)$ & Plasebo $(\mathrm{n}=17)$ & $\mathrm{p}$ \\
\hline Episode residu (kali) selama pemantauan (rentang) & $0(0-4)$ & $1(0-9)$ & 0,271 \\
\hline Lama hari mencapai nutrisi enteral penuh (hari) & $8(6-11)$ & $8(6-14)$ & 0,827 \\
\hline
\end{tabular}


pada kedua kelompok, tetapi tidak bermakna secara statistik ( $\mathrm{p}=0,271)$ (Tabel 2).

Analisis subgrup episode terjadinya residu pada bayi di UG $<32$ minggu, yaitu $0(0-4)$ kali pada kelompok eritromisin, dan 1 (0-6) kali pada kelompok plasebo selama pemantauan. Terdapat perbedaan median episode residu antara kedua kelompok penelitian yang tidak bermakna secara statistik, baik pada $U G \leq 32$ minggu ( $p=0,251)$, maupun pada $U G$ $>32$ minggu $(\mathrm{p}=0,39)$ (Tabel 3$)$. tersebut bekerja dengan cara meningkatkan tekanan sfingter esofagus bagian bawah, mempercepat pengosongan lambung, menstimulasi usus halus, dan memperpendek waktu transit di kolon. ${ }^{10}$ Eritromisin diketahui memiliki efek prokinetik sejak tahun 1980. Efek prokinetik eritromisin dimanfaatkan untuk pengobatan pasien anak dan dewasa dengan gangguan fungsi saluran cerna akibat pseudoobstruksi kronis, refluks gastroesofagus, dismotilitas usus pasca-operasi, gastroparesis sekunder pada diabetes, dan setelah

Tabel 3. Analisis subgrup episode terjadinya residu selama pengobatan dan lama hari mencapai nutrisi enteral penuh setelah perlakuan

\begin{tabular}{|c|c|c|c|c|c|c|}
\hline & \multicolumn{6}{|c|}{ Usia gestasi (minggu) } \\
\hline & \multicolumn{3}{|c|}{$\leq 32$} & \multicolumn{3}{|c|}{$>32$} \\
\hline & \multicolumn{3}{|c|}{ Jenis perlakuan } & \multicolumn{3}{|c|}{ Jenis perlakuan } \\
\hline & $\begin{array}{c}\text { Eritromisin } \\
(\mathrm{n}=13)\end{array}$ & $\begin{array}{c}\text { Plasebo } \\
(\mathrm{n}=12)\end{array}$ & $\mathrm{p}$ & $\begin{array}{l}\text { Eritromisin } \\
\quad(\mathrm{n}=6)\end{array}$ & $\begin{array}{c}\text { Plasebo } \\
(\mathrm{n}=5)\end{array}$ & $\mathrm{p}$ \\
\hline $\begin{array}{l}\text { Episode terjadinya residu (kali) } \\
\text { selama pemantauan (rentang) }\end{array}$ & $0(0-4)$ & $1(0-6)$ & 0,251 & $0(0-4)$ & $2(0-9)$ & 0,39 \\
\hline $\begin{array}{l}\text { Lama hari mencapai nutrisi enteral } \\
\text { penuh (hari) } \pm \mathrm{SB}^{*}\end{array}$ & $8 \pm 2$ & $9 \pm 3$ & 0,61 & $8 \pm 1$ & $7 \pm 2$ & 0,60 \\
\hline
\end{tabular}

\section{Lama hari mencapai nutrisi enteral penuh}

Median lama hari mencapai nutrisi enteral penuh setelah perlakuan, yaitu 8 (6-11) hari pada kelompok eritromisin, dan 8 (6-14) hari kelompok plasebo. Perbandingan median lama hari mencapai nutrisi enteral penuh antara kedua kelompok tidak terbukti bermakna secara statistik ( $\mathrm{p}=0,827)$ (Tabel 2).

Analisis subgrup rerata waktu yang dibutuhkan bayi dengan UG $\leq 32$ minggu mencapai nutrisi enteral penuh setelah diberikan perlakuan adalah $8 \pm 2$ hari pada kelompok eritromisin, dan $9 \pm 3$ hari pada kelompok plasebo. Perbedaan waktu mencapai nutrisi enteral penuh antara kedua kelompok tidak berbeda bermakna secara statistik $(\mathrm{p}=0,61)$. Rerata lama mencapai nutrisi enteral penuh pada bayi dengan $U G>32$ minggu pada kelompok eritromisin adalah $8 \pm 1$ hari, dan kelompok plasebo $7 \pm 2$ hari. Keduanya juga tidak memiliki perbedaan bermakna berdasarkan uji-t $(\mathrm{p}=0,60)$ (Tabel 3).

\section{Pembahasan}

Obat prokinetik mengandung senyawa yang dapat menstimulasi fungsi motorik saluran cerna. Obat operasi vagotomi. Penggunaan eritromisin kemudian diperluas untuk bayi prematur dengan dismotilitas saluran cerna. ${ }^{11}$

Aktivitas prokinetik eritromisin mirip dengan motilin. Peningkatan konsentrasi motilin dalam plasma berkaitan dengan migrating motor complex (MMC), yaitu suatu siklus aktivitas elektromekanik yang berfungsi untuk membersihkan residu material yang tidak dapat dicerna, muncul secara konsisten setelah UG 32 minggu. Aktivitas MMC terdiri dari 3 siklus, yaitu fase 1 yang merupakan fase diam, fase 2 bersifat lebih aktif dengan kontraksi yang bersifat intermitten dan irregular. Puncak aktivitas MMC adalah fase 3 yang berlangsung selama 5-10 menit, berupa rentetan kontraksi dengan peningkatan frekuensi dan kecepatan kontraksi, bersifat singkat, ritmik, kuat, dan mendorong ke arah duodenum. ${ }^{12}$

Pengaturan aktivitas MMC secara detail belum diketahui pasti, tetapi penelitian pada bayi UG 2442 minggu menunjukkan bahwa fase 3 dapat dipicu oleh rangsangan dari motilin. ${ }^{12}$ Motilin merupakan suatu polipeptida yang terdiri dari 22 asam amino, disekresikan oleh sel-sel enterokromafin di usus halus secara periodik ke sirkulasi darah dan dapat memicu kontraksi otot polos saluran cerna. Reseptor motilin 
telah diidentifikasi dan sebagian besar berada di bagian atas saluran cerna dengan konsentrasi maksimal di daerah antrum. ${ }^{13,14}$

Eritromisin mempunyai afinitas yang tinggi terhadap reseptor motilin. ${ }^{15}$ Stimulasi dari reseptor motilin memicu akivitas MMC sehingga menyebabkan peningkatan kontraksi antrum dan menurunkan tahanan pilorus. ${ }^{16,17}$ Penurunan tahanan pilorus merupakan mekanisme kontrol yang penting untuk pengaliran isi lambung. ${ }^{18}$ Fluktuasi motilin plasma tidak terlihat pada bayi prematur yang mungkin meyebabkan atau kurangnya aktivitas MMC. ${ }^{15}$

Beberapa penelitian terdahulu menunjukkan bahwa eritromisin yang diberikan per oral maupun intravena dapat meningkatkan motilitas saluran cerna pada bayi prematur dengan intoleransi minum. Manfaat eritromisin sebagai prokinetik digunakan baik sebagai profilaksis atau terapi. Eritromisin sebagai profilaksis diberikan pada bayi yang mempunyai risiko intoleransi minum sebelum atau bersamaan dengan dimulainya pemberian nutrisi enteral, sedangkan sebagai terapi eritromisin diberikan pada bayi yang sudah menunjukkan gejala klinis intoleransi minum. Pemberian eritromisin sebagai profilaksis atau terapi dapat dikelompokkan lagi menurut dosis, yaitu eritromisin dosis rendah (3-12 mg/ $\mathrm{kgbb} / \mathrm{hari}$ ) dan dosis tinggi (>12 mg/kgbb/hari). ${ }^{9}$ Dosis rendah (1-3 mg/kgbb/dosis) eritromisin dapat memicu aktivitas MMC, sedangkan dosis lebih tinggi (10-12,5 $\mathrm{mg} / \mathrm{kgbb} /$ dosis) dapat meningkatkan kontraksi antrum dan mempertahankan aktivitas MMC. ${ }^{19}$ Eritromisin dosis rendah dapat menurunkan volume residu lambung dan memperpendek waktu transit usus pada bayi prematur, sehingga waktu pencapaian pemberian nutrisi enteral penuh (full feed) lebih cepat. ${ }^{20,21}$

Kami tidak mendapatkan perbedaan episode terjadinya residu pada kelompok eritromisin dan plasebo. Hasil tersebut serupa dengan uji klinis acak tersamar ganda yang dilakukan oleh ElHennawy $\mathrm{dkk}^{22}$ di Texas yang melibatkan 26 bayi prematur dengan UG 29-36 minggu. Dosis eritromisin yang digunakan sebagai terapi pada penelitian tersebut yaitu $1,5 \mathrm{mg} / \mathrm{kgbb} /$ dosis setiap 6 jam selama 8 hari. Penilaian terhadap pengosongan lambung dilakukan dengan menggunakan antroduodenal manometri yang ditempatkan di antrum dan duodenum. Hasil penelitian tersebut melaporkan tidak terdapat perbedaan dalam waktu pengosongan lambung dan secara klinis terlihat tidak terdapat perbedaan bermakna pada episode terjadinya residu pada kedua kelompok.
Analisis subgrup dengan cut of point UG 32 minggu menunjukkan tidak terdapat perbedaan bermakna pada kedua kelompok baik pada UG $\leq 32$ maupun $>32$ minggu. Hasil berbeda dilaporkan oleh Aly dkk ${ }^{23}$ yang melakukan penelitian terhadap 60 bayi prematur dengan UG $\leq 37$ minggu di Mesir. Terdapat median episode residu yang lebih kecil secara bermakna pada kelompok eritromisin (dosis $1 \mathrm{mg}$ / $\mathrm{kgbb} /$ dosis, setiap 8 jam) dengan UG $>32$ minggu, tetapi tidak ada perbedaan pada UG $<32$ minggu. Keseragaman penelitian Aly dkk tersebut juga lebih baik dibandingkan penelitian kami karena dilakukan di 1 senter dan jenis susu yang diberikan pada tiap bayi sama, dengan kontrol peningkatan volume minum sepenuhnya dilakukan oleh peneliti.

Hasil bermakna pengurangan episode residu lambung pada pemberian prokinetik eritromisin dosis rendah (1,5-2,5 mg/kgbb/6 jam) dilaporkan oleh dua penelitian di Australia dan Singapura. Kedua penelitian merupakan uji klinis acak terkontrol yang dilakukan pada satu institusi. Namun, kedua penelitian tersebut memberikan eritromisin dosis rendah sebagai profilaksis, bukan sebagai terapi. ${ }^{24,25}$

Pada penelitian kami, waktu yang dibutuhkan untuk mencapai nutrisi enteral penuh tidak berbeda bermakna atara kelompok eritromisin dan plasebo. Hasil tersebut serupa dengan uji klinis acak terkontrol yang dilakukan oleh Cairns $\mathrm{dkk}^{26}$ terhadap 60 bayi prematur UG $<37$ minggu di Kanada yang melibatkan 3 senter rumah sakit. Eritromisin diberikan sebagai terapi dengan dosis yang sama dengan penelitian kami, yaitu $3 \mathrm{mg} / \mathrm{kgbb} /$ dosis setiap 6 jam, tetapi dengan cara pemberian yang berbeda, yaitu melalui intravena.

Dosis eritromisin $5 \mathrm{mg} / \mathrm{kgbb} /$ dosis setiap 8 jam sebagai terapi intoleransi minum yang digunakan dalam uji klinis oleh $\mathrm{Ng} \mathrm{dkk}^{27}$ di Singapura terhadap 24 bayi prematur juga tidak menemukan perbedaan lama hari mencapai nutrisi enteral penuh antara kelompok eritromisin atau plasebo. Kelompok eritromisin menunjukkan waktu nutrisi enteral penuh yang lebih cepat, yaitu $24,9 \pm 2,9$ hari vs $30,8 \pm 4,1$ hari, tetapi secara statistik hal tersebut tidak bermakna.

Analisis subgrup yang dilakukan terhadap kelompok UG $\leq 32$ minggu ataupun $>32$ minggu juga menunjukkan pemberian eritromisin tidak memengaruhi waktu yang dibutuhkan untuk mencapai nutrisi enteral penuh. Penelitian prospektif acak tersamar ganda yang dilakukan Aly dkk ${ }^{23}$ dengan dosis $1 \mathrm{mg} / \mathrm{kgbb} /$ dosis di Mesir mendapatkan waktu yang lebih singkat secara 
bermakna pada bayi UG >32 minggu yang menerima eritromisin sebagai terapi, tetapi pada bayi UG $\leq 32$ minggu tidak terlihat perbedaan bermakna.

Penelitian mengenai efektifitas eritromisin sebagai terapi untuk mengatasi intoleransi minum yang dilakukan di Hongkong oleh $\mathrm{Ng} \mathrm{dkk}^{28}$ dan Bangkok oleh Nuntnarumit $\mathrm{dkk}^{29}$ mendapatkan hasil yang berbeda. Eritromisin dilaporkan dapat mempercepat waktu mencapai nutrisi enteral penuh. Perbedaan penelitian kami dengan kedua penelitian tersebut, yaitu dosis tinggi yang digunakan $(10-12,5 \mathrm{mg} / \mathrm{kgbb} / 6$ jam) sebagai terapi. Penelitian serupa terhadap 45 bayi prematur oleh Yan $\mathrm{dkk}^{30}$ di Taiwan menyimpulkan pemberian eritromisin dapat mempercepat waktu mencapai nutrisi enteral penuh secara bermakna. Selain memiliki subyek yang lebih besar, penelitian ini juga menggunakan dosis eritromisin yang lebih tinggi (5 $\mathrm{mg} / \mathrm{kg} /$ dosis setiap 6 jam) dengan waktu pemberian yang lebih panjang, yaitu 14 hari.

Kontroversi mengenai efikasi eritromisin sebagai prokinetik pada bayi prematur dengan intoleransi minum sampai saat ini masih terus berlangsung. Penelitian kami merupakan penelitian pertama di Indonesia mengenai manfaat eritromisin sebagai terapi pada intoleransi minum. Keterbatasan penelitian kami, yaitu pengukuran motilitas lambung hanya dinilai secara klinis dengan mengukur jumlah residu dan lama waktu pencapaian nutrisi enteral penuh. Baku emas penilaian motilitas lambung secara obyektif menggunakan metode manometri antroduodenal tidak dapat dilakukan karena ketersediaan alat tersebut masih sangat terbatas. Sepsis yang dijadikan kriteria eksklusi dengan tujuan untuk mendapatkan subyek dengan klinis yang homogen untuk mengurangi bias menjadi faktor penyulit utama dalam melakukan perekrutan subyek penelitian. Keterbatasan lainnya adalah jumlah subyek kurang dari yang diharapkan dan ketidakseragaman prosedur pemberian minum pada tiap rumah sakit. Prosedur pemberian obat dan aspirasi residu lambung dapat diseragamkan pada tiap senter, namun peneliti tidak dapat mengintervensi standar prosedur operasional kenaikan jumlah pemberian minum bayi prematur pada tiap rumah sakit tempat penelitian.

\section{Kesimpulan}

Pemberian eritromisin dosis rendah per oral (3 $\mathrm{mg} / \mathrm{kgbb} /$ dosis, setiap 6 jam) selama 7 hari tidak terbukti dapat mengurangi residu lambung maupun mempercepat pencapaian nutrisi enteral penuh pada bayi prematur dengan UG 28-36 minggu yang mengalami intoleransi minum. Perlu dilakukan penelitian lebih lanjut untuk mengetahui efikasi eritromisin dalam meningkatkan toleransi minum pada bayi prematur dengan jumlah sampel yang lebih besar dan menyeragamkan metoda penelitian, seperti standar prosedur kenaikan jumlah pemberian minum dan cara pemberian susu. Pemberian eritromisin sebagai obat prokinetik dosis tinggi juga perlu dipertimbangkan mengingat resistensi yang dapat ditimbulkan oleh eritromisin sebagai antibiotik.

\section{Daftar pustaka}

1. Cho SJ. Enteral nutrition of the premature infant. Korean J pediatr 2010; 53:7-13.

2. Nogami K, Nishikubo T, Minowa H, Uchida Y, Kamisutji $\mathrm{H}$, Takahashi Y. Intravenous low-dose erythromycin administration for infants with feeding intolerance. Pediatr Int 2001; 43:605-10.

3. Doherty WL, Winter B. Prokinetic agents in critical care. Crit Care 2003; 7:206-8.

4. UCSF Children's Hospital. Feeding of preterm infants. [diakses pada: 27 Agustus 2007]. Diunduh dari: http:// www.ucsfhealth.org/childrens/health_professionals.

5. Clure RJ, Newel SJ. Randomised controlled study of clinical outcome following trophic feeding. Arch Dis Child Fetal Neonat 2000; 82:29-33.

6. Zatman TF, Hall JE, Harmer M. Gastric residual volume in chldren: a study comparing efficiency of erythromycin and metoclopramide as prokinetic agents. $\mathrm{Br} \mathrm{J}$ Anaesth 2001; 86:869-71.

7. Lewin MB, Bryant RM, Fenrich AL, Grifka RG. Cisapride-induced long QT interval. J Pediatr 1996; 128:279-81.

8. Stevens JE. Study of gastric motility in health and diabetes (thesis). Adelaide: Discipline of Medicine University of Adelaide, 2009.

9. $\mathrm{Ng}$ E, Shah VS. Erythromycin for the prevention and treatment of feeding intolerance in preterm infants. Cochrane Database of Systematic Reviews 2008, Issue 3. Art.No.: CD001815. DOI:10.1002/14651858. CD001815.

10. McQuaid KR. Drug used in the treatment of gastrointestinal disease. Dalam: Katzung BG, penyunting. Basic clinical pharmacology. Edisi ke-9. New York: 
McGraw-Hill; 2004. h. 1034-63.

11. So AKW, Ng PC, Fok TF. GI dysmotility in preterm infants. HK J Pediatr 2003; 8:101-6.

12. Jadcherla SR, Klee G, Berseth CI. Regulation of migratory motor complexes by motilin and pancreatic polypeptide in human infants. Pediatr Res 1997; 42:3659.

13. Feighner SD, Tan CP, McKee KK, Palyha OC, Hreniuk D, Pong SS. Receptor for motilin identified in the human gastrointestinal system. Science 1999; 284:2184-8.

14. Miller P, Roy A, Pierre S, Dagenais M, Laponte R, Poitras P. Motilin receptor in the human antrum. Am J Physiol 2000; 278:18-23.

15. Peeters T, Matthijs G, Depoortere I, Cachet T, Hoogmartens J, Vantrappen G. Erythromycin is a motilin receptor agonist. Am J Physiol 1989; 257:4704.

16. Otterson MF, Sarna SK. Gasrointestinal motor effects of erythromycint. Am J Physiol 1990; 259:355-63.

17. Mathis $\mathrm{C}$, Malbert $\mathrm{CH}$. Changes in pyloric resistance induced by erythromycin. Neurogastroenterol Motil 1998; 10:131-8.

18. Coulie B, Tack J, Peeters T, Janssens J. Involvement of two different pathways in the motor effects of erythromycin on the gastric antrum in humans. Gut 1998; 43:395-400.

19. Thomas EY. Pharmacologic treatment of feeding intolerance in neonates. NeoReviews 2010; 11:139-43.

20. Dellagrammaticas HD, Iacovidou N, Megaloyanni E, Papadimitrion M, Kapetanakis J. Effect of low-dose oral erythromycin on gastric aspirates in ventilated neonates less than 32 weeks of gestation. Bio1 Neonate 2002; 81:213-6.

21. Costalos C, Gavrili V, Skouteri V, Gounaris A. The effect of low-dose erythromycin on whole gastrointestinal transit time of preterm infants. Early Hum Dev 2001; 65:91-6.
22. ElHennawy AA, Sparks JW, Armentrout D, Huseby V, Berseth C. Erythromycin fails to improve feeding outcome in feeding-intolerant preterm infants. J Pediatr Gastroenterol Nutr 2003; 37:281-6.

23. Aly H, Abdel-Hady H, Kashaba M, El-Badry N. Erythromycin and feeding intolerance in premature infants: a randomized trial. J of Perinatol 2007; 27:3943.

24. Oei J, Lui K. A placebo-controlled trial of low dose erythromycin into promote feed tolerance in preterm infants. Acta Pediatr 2001; 90:904-8.

25. Mohammadizadeh M, Ghazinour M, Iranpour R. Efficacy of prophylactic oral erythromycin to improve enteral feeding tolerance in preterm infants: a randomised controlled study. Singapore Med J 2010; 51:952-6.

26. Cairns PA, Craig S, Tubman R. Randomised controlled trial of low-dose erythromycin in preterm infants with feed intolerance. Pediatr Res 2002; 51:379-80.

27. Ng SC, Gomez JM, Rajadurai VS, Saw SM, Quak SH. Establishing enteral feeding in preterm infants with feeding intolerance: a randomised controlled study of low dose erythromycin. J Pediatr Gastroenterol Nutr 2003; 37:554-8.

28. Ng PC, So KW, Fung KSC, Lee CH, Fok TF, Wong E. Randomised controlled study of oral erythromycin for treatmenr of gastrointestinal dysmotility in preterm infants. Arch Dis Child Fetal Neonat 2001; 84:17782.

29. Nuntnarumit P, Kiatchoosakun P, Tantiprapa W, Boonkasidecha S. Efficacy of oral erythromycin for treatment of feeding intolerance in preterm infants. J Pediatr 2006; 148:600-5.

30. Yan N, Su PH, Chen YJ, Quek YW, Hu JM, Lee IC. Efficacy of intermediate-dose oral erythromycin on very low birth weight infants with feeding intolerance. Pediatrics and Neonatology 2012; 53:34-40. 